\title{
Academic Staff Retention in Private Universities in Southern Highland Zone Tanzania as a Strategy of Attaining Sustainable Development
}

\author{
Sr. Dr. Demetria Gerold Mkulu PhD \\ Department of Education Foundation \\ St Augustine University \\ Tanzania
}

\begin{abstract}
Universities are relied upon by the society to conserve, create and disseminate knowledge which is in realization of sustainable development in Tanzania. This study aims at exploring on academic staff retention in private universities in Southern Highlands Zone in Tanzania as a strategy of attaining sustainable development. The study was anchored on Herzberg theory of motivation. Cross sectional survey and phenomenology design were employed. Five private universities were sampled involving 200 participants. Data was collected through questionnaires, in-depth interview guide and document analysis. Qualitative data was analyzed by identification of patterns, categories, and themes in order to get multiple realities. Results indicated that low remuneration in workplace leads to high rate of attrition and low retention, delay in payment in private universities, a wanting leadership style, lack of job security and low academic staff career development. The paper concluded that the government needs to involve in the funding operations.
\end{abstract}

Keywords: Academic Staff, Retention, Attrition, Sustainable Development, Motivation

\section{Introduction}

Academic staff-employer relationship has undergone fundamental changes. Lecturer attrition rates vary widely between developed and developing countries including Tanzania. Statistics from the International Task Force report on Teachers for All, TFA

(2010) demonstrated that in New Zealand, academic staff attrition in private universities alone rose to10.4 percent per year, in England 9 percent and in USA13.6 percent. This is similar to a report from the annual education statistics in Bhutan, Perden (2013) which showed that in 2008 to 2013 alone, a total of 750 lecturers voluntarily resigned, 207 eft after contract expiration. The findings indicated that lecturers left the teaching profession due to low pay. In African countries: the turnover is 15 percent per year in Malawi and 14 percent in Zambia. In South Africa, lecturers quit due to the leadership style and low remuneration (Muteswa, 2012). In Kenya, out of one million Kenyans who moved to developed countries, about 40 percent are lecturers from private universities as explained by (Owuor, 2010).

However, Pienaar (2008) asserted that the crucial role of the University education is to prepare most of the professionals who develop, lead, manage, $\mathrm{t}$ each, and influence society's institutions. Hence the retention of academic staff is the pillar to the functioning of any university. Sustainable development was first introduced at the first Summit in 1972 in Stockholm. Since then momentum for sustainable development has been spreading global including African countries. Overall, sustainability is about building strong, resilient communities where everyone has access to the resources needed to achieve a high quality of life without exceeding the capacity of our natural ecosystems. Academic staff Retention is very crucial for Sustainable Development. The question is how private universities are addressing sustainable development in Tanzania specifically in Southern Highland Zone. The private universities should attract and retain skilled academic staff that means creating community of purpose for academic staff, as well as other stakeholders, be values led organization, and ensure healthy workplace (Pienaar, 2008).

One of the goals of sustainable development is to ensure quality education and promote lifelong learning. Provision of quality education will not be realized if lecturers are quitting every day, hence retention is highly needed in all universities so as provision of sustainable development. 
Top management in private universities should support an adaptive and flexible process towards inevitable changes in lecturers' retention which has a direct effect on students' achievement. However sustainable development has also been criticized as overly value-based. Sustainability and sustainable development are normative terms and placing them as desired outcomes of education is more reminiscent of indoctrination. Therefore education sustainable development would be experienced in universities if University managers would retain lecturers (Lisa, Jos, Beishuizen, Zijilsta \& Monique, 2017).

\subsection{Statement of the Problem}

Academic staff retention is a global issue, lecturers are moving from private to public universities, while other lecturers change their professional work. However education policy in Tanzania encourages private organizations and social groups to establish higher education institutions including universities. There is 26.1 percent academic staff attrition, 20.6 percent academic staff retirement and 8.5 percent natural attrition. Education Sector Development (ESD, 2012) reports that academic staff attrition in private and public universities in Tanzania are at 70.9 percent. Academic staff retention in the Southern Highland zone has been a major issue yet it is least researched and documented. Southern Highland zone is one of the zones in Tanzania that is facing low retention of lecturers from private universities. If this trend is not arrested, there is a possibility of losing large percentage of potential lecturers to other organizations. This could in future cripple private university education in Tanzania. Therefore, the intent of the current study was to find out if private universities have administrative strategies for retention of academic staff or not.

\section{Literature Review}

Looking at the contribution of motivation, Lawler and Fuchs (2010) examined strategies for retention at Cornell University, USA. The study indicated that universit y management placed the highest priority on lecturers and students to sustain and enhance faculty excellence and leadership in research. The management also emphasized on promoting, valuing, treating all individuals with dignity, respect, fairness, and recognizing academic staff. The findings indicated that lecturers were highly motivated and the university was ranked among the top ten in the world. However, the study's weakness was that it focused on a single university and failed to indicate the methodology used. The shortcoming was the research was done in a developed country while the current study was conducted in a developing country in Africa.

In North Greece, Platsidou and Diamantopoulou (2009) investigated whether job satisfaction was affected by demographic factors such as gender and academic rank, among others. Using a sample of 105 respondents from 4 universities in North Greece, the findings revealed that Greek academicians were dissatisfied with their job because most felt that with the rise in academic rank, one should be paid more. The current study found out if the same perception holds true in developing nations, by determining whether academic rank has any effect on turnover in private universities.

Moreover, Ahuja and Kumar (2012) studied faculty motivation at Bhattal Universit y Punjab, India. The researchers established the relationship between motivation and faculty turnover in universities in India. The findings indicated that faculty members had different levels of education, experience, and skills. Therefore, the same motivation policies could not satisfy all faculty categories of professor, assistant professor, senior lecturers, and lecturers. The main weakness of this study is that it does not indicate the methodology used or even the number of respondents.

A study conducted by Owuor (2010) examined on academic mobility and brain drain in East Africa with Kenya as the case study. The study deliberately focused on the mobility of academic staff within and across East African countries. The findings indicated that there was high movement of lecturers from African universities to overseas due to inadequate pay, poor policies, and bad working conditions. In Kenya, Wafula (2013) looked at employee's perception of remuneration schemes in private universities. The study involved 136 respondents, both teaching and non- teaching staff, from whom data was collected using questionnaires. The findings showed that remuneration is the key factor for retaining academic staff in private universities. However, some employees may quit their jobs even though they receive a high salary.

\subsection{Leadership Style and Academic Staff Retention}

Looking at the contribution of leadership style on lecturer retention, Blazer (2006) conducted a study on lecturer attrition in private colleges in Florida, USA using a case study. He discovered that 20 percent of lecturers left their profession after three years and close to 30 percent left after five years. 
The characteristics of lecturers who moved and the leadership styles of universities were likely to make them leave. The general findings of the study were that, the impact of work environment, leadership style, and lack of compensation caused academic staff to move from one place to another. Autocratic leadership style and motivation were the main catalysts of academic staff turnover. The study above has several drawbacks. First, it was conducted in a developed country (USA). Second, the fact that it was done in 2006 means there is a time gap. Finally, Blazer did not indicate how many university colleges were sampled. These gaps may be filled by the current study, which sampled multiple universities, hence generated richer data on the phenomenon being studied.

In the same vein, Leahy (2012) examined lecturer turnover in Northern Carolina, USA. The study sampled both public and private universities. However, the methodology used was not defined clearly. The findings indicated that lecturers in private universities were highly motivated by higher pay in the traditional mold of "pay and benefit". Some universities remunerated lecturers by awarding them fringe benefits and offering other reward systems such as day care and staff development. However, Dillow (2013) suggests that remuneration alone may not be sufficient to motivate academic staff to remain at a university. In addition, it was found that influence of democratic leadership style should serve to motivate employees. This is in line with Butten (2013) who contends that, leadership should play the role of motivating employees. The current study built on the researches cited above, by examining the broader set of strategies used at the workplace.

Looking at the influence of administrative and leadership style on lecturer turnover in USA, Body et al. (2009) carried out a study which applied survey designs on new lecturers. The findings indicated that demographic factors such as work experience consistently predicted turnover. Lack of motivation, leadership styles and working conditions also contributed at least partly to higher attrition of lecturers. Finally, they noted that turnover is higher among young and old lecturers than among middle-aged and less experienced lecturers.

Moreover, Miller (2011) Examined on how organization managers influenced lecturers to leave Georgia State University. The researcher used a single research method. Among them 16 participants were included in the study. The study used Maslow's theory of motivation. The study indicated that lecturers decided to quit the Universit y due to leadership style, lack of professionalism, the manager's lack of respect and trust, inconsistent behavior and lack of personal morals.

In addition, they show appreciation for work done (Phrasisombath, 2012; Northouse, 2010). The previous study used a single instrument for data collection and a single methodology. The sample was not clearly stated. The study by, Veiseh and Veisi (2014) conducted on how servant leadership style contributes to retention at the University of Ilam in India. The finding demonstrated that the most influential factors were service, kindness, and humility respectively to the lecturers. The current study sought to find out what kind of leadership style is practiced in the Southern Highland Zone and their contribution to academic staff retention.

Similarly, Negi (2013) researched on the role of transformational leadership style in controlling attrition and enhancing retention in the workplace in India. The study did not indicate what sample, method of data collection and data analysis were used. The researcher used Herzberg Theory of Motivation. The finding indicated that leadership can play a pivotal role in curbing attrition. A change in the workplace environment should change the style of the manager too. In addition, leaders need to appreciate open discussions, have a welcoming attitude and promote workers. Transformational managers can affect the organization by creating new ways to engage employees, inspire motivation and solve old problems. This kind of leadership style empowers workers to retrieve their hidden skills and talent. However, Negi failed to indicate his methodology, method of data collection and analysis. The current study filled the gap by using the mixed methods approach in a sample of five universities. Marn (2012) investigated the impact of transformation leadership practices on job satisfaction and lecturer turnover in universities in Kuala Lumpur, Malaysia. The study involved 100 lecturers and employed the survey design. The findings indicated that leadership influenced job satisfaction and contributed to higher turnover or retention of lecturers in private universities. Marn contends that leadership style affects employee job satisfaction, commitment and productivity.

In Kenya, Ng'ethe (2012) conducted a study on how leadership contributes to retention of lecturers. The study used seven public universities; data was collected from 547 lecturers. The study asserted that role of managers and their leadership style contributed greatly in retaining workers. The role of the university managers in employee retention is vital. Hence, there is need to embrace a leadership style that empowers employees to remain in the workplace. 
The findings indicate that public universities function in a vastly competitive atmosphere, and that leadership styles greatly influence lecturers' retention. However, $\mathrm{Ng}$ 'ethe did not indicate the methodology used in the study.

The study by Mwita (2013) investigated the challenges facing public universities in Tanzania. The research applied the mixed methods approach with 155 respondents filling in a questionnaire. Interviews were conducted on a few participants on phone and face-to- face. The findings indicated that MUCE had a high staff turnover, the number of students allocated to each course was too high and the university lacked the required facilities for learning. A major weakness of this study is that, it does not propose strategies for curbing the problem.

In Tanzania, Kavenuke (2013) examined factors that keep lecturers in the teaching profession at Dar es Salaam University. The findings indicate that lecturers leave the teaching profession due to demographic factors such as gender, age, education, and experience. Gender accounts for the highest attrition rates in men. Family reasons such as maternity and marriage contribute highly to attrition. In addition, highly skilled

Lecturers are more likely to quit than their less skilled peers. In other words, the more specialized knowledge and experience employees have, the greater the probability of them moving or changing jobs. However, this study did not point out clearly the methodology used.

\subsection{Summary and Knowledge Gap}

Overall, the reviewed studies indicate that academic staff retention in private universities is a global concern (Task Force Report on Teachers for All, 2010; Boyd et al., 2011, Virginia, USA; SHRM, 2012, in USA). Moreover, studies on retention revealed that attrition was cited as being quite high in private universit ies whereas retention remained very low at a global average of 10 percent (Global Education Watch (GEW), 2013).

However, the reviewed studies revealed that majority of academic staff leave the workplace due to poor remuneration. This has been researched extensively in developed countries. Other studies focused on conducive workplace environment, leadership style such autocratic, transformative, democratic, servant, transaction, and lack of motivation to lecturers which contribute significantly to attrition (Clotfelter et al., (2007) Duke University, USA; Mwangu \& Leshabari, (2008) Muteswa, (2012) South Africa. Lack of staff development opportunities and for individual development contributes to lecturer dissatisfaction and staff attrition. Other studies indicate that lecturers will be retained in the workplace environment if the employee has a good relationship with the leadership and co-workers (Blazer, 2006 Miami Florida USA; Leahy, 2012, in Northern Carolina in USA. Studies also found that job security, promotion, recognition of each staff member's contribution, and job enrichment all contribute to academic staff retention.

Most of the studies conducted on retention of academic staff in both private and public universities employed single methods for data collection with limited samples (Wambui, 2014, Kenya; Nderitu, 2014, in Kenya; Calhoun, 2009; Gberevbie,2009) in Nigeria. Most of them were carried out in developed countries (Tickle, 2009, Virginia USA; Lawler \& Fuchs, 2010; Platsidou \& Diamantopoulous, (2009) North USA. Some do not define how data was collected and analyzed and what the methodology was (Namasaka et al., 2013 in Kenya; Lee et al., 2008; Mkude, 2007 in Tanzania).

The current study used quantitative and qualitative paradigm in a single study. Also, the study was conducted in a developing country, a fact that adds to the significance of the study and helps to fill in the knowledge gap. Quite a number of studies on attrition and retention have focused on developed countries, yet attrition of academic staff is alarmingly high in developing countries. Finally, researches done in Southern Highlands Zone in Tanzania have tended to focus on primary and secondary levels of education and not on universities which have major challenges with attrition and retention of lecturers. Documented studies on retention of lecturers in developing countries are minimal indicated. Where they are available, they are limited, hence the need to conduct such a study in the Southern Highland Zone in Tanzania.

\section{Research Methodology}

This study was a mixed approach research hence the researcher used convergent parallel research Design. Mixed research designs allow quantitative and qualitative to be used in a single study. Cross sectional survey was employed for quantitative data while phenomenology design was used for qualitative aspect. In the current study data was collected concurrently and analyzed separately and merge at the end. 


\subsection{Sample Size and Sampling Procedure}

The researcher employed stratified sampling, systematic sampling, simple random sampling, and purposive sampling in the study which give a total of 250 respondents. The researcher was interested to use lecturers in this study because they had experience about the academic staff transit from one university to another. Hence they provided relevant data. University administrators such as deans and heads of departments were involved in the study because by positions, they were influential in recruiting, motivating and inducting lecturers. They also supervised curriculum implementation and were in a position to provide information on what happens in their respective universities. Third year students were included in the study because they had been in the universities for long and were thus aware of the issue of academic staff attrition. In addition, students at this level of education know the effects of lecturer attrition

\subsection{Research Instruments}

The current study employed the questionnaires, interview guide and document analysis

\subsection{Validity and Reliability of Instruments}

The instruments were content-and face-validated by subjecting them to thorough scrutiny to experts in research Department. The constructive feedback and responses received from these supervisors were then used to improve on the content of the instruments before administered to respondents.

\subsection{Reliability of Instruments}

The internal consistency of the instruments was determined by computing the Cronbach's Alpha. An overall alpha statistic was 0.90 respectively, indicating that the instruments were reliable

\section{Findings and Discussion}

The findings in this study were structured around the three overarching research questions and closely reflect the analytical framework adopted as backbone of the study. The research was interested to find out if the lecturers in Southern Highland Zone leave their workplace to go to new places of work, while some change their work. The following were the responses from the administrators.

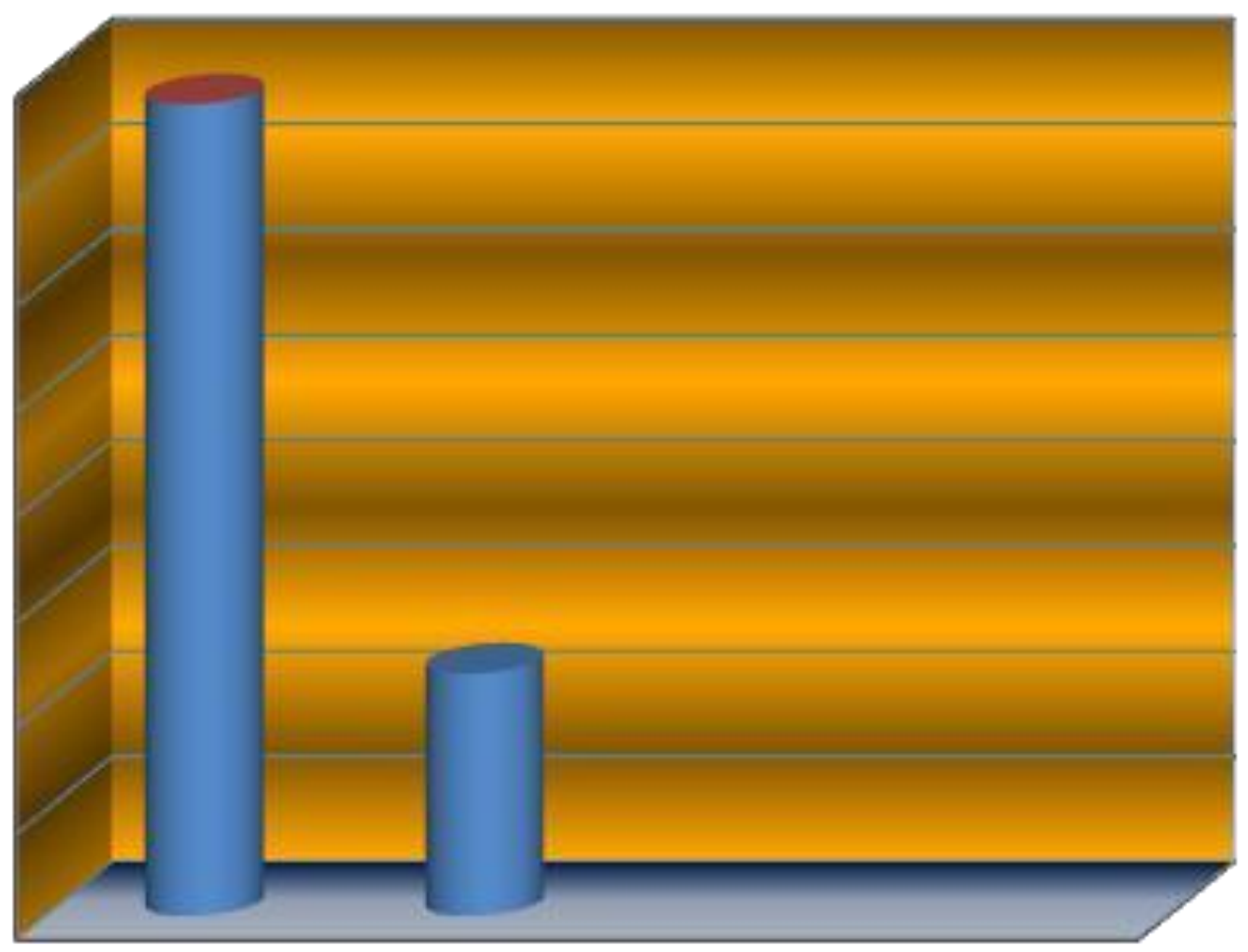

Figure 1 Demonstrate the academic staff retention and attrition in private 
The findings in figure 1 highlights that 77 percent of the academic staff left the University for less than two years while 23 percent of $\mathrm{t} \mathrm{h}$ e academic staff was retained do the work place .This implies that the rate of academic staff attrition is higher than retention in Southern Highland Zone in Tanzania. When the participants were interviewed, they responded saying that indeed academic staff leaves private Universities and that there is no doubt about it. One respondent emphatically said: Without improving the work place environment such as physical and social environment, we shall continue to quit these private Universities. Even as I talk now, there are seven lecturers who are intending to leave. Three of us have submitted resignation letters just waiting to leave (Tabi, 9th August 2015).

The Universities have a duty as such to work on various strategies in improving remuneration issues, motivation and training so as to enhance retention of academic staff in Private Universities. Academic staff left private universities in Southern Highland Zoneforthepasttwoyears.Thestudyfindingsalsodemonstratedthatprivate universities must embrace lecturer's motivation, such as lecturer's rank, lecturer's recognition, appreciation; flexibility and career development are the key factors for retaining individual to remain in the university. This was in line with Lawler and Fuchs (2010 who indicated that university management placed the high estpriorityon students to sustain and enhance academic excellence and not on lecturers. The study was also interested in obtaining the challenges faced by academic staff, retention and attrition of academic staff in Private Universities in the Southern Highlands Zone, Tanzania, as indicated in table1

\section{Table 1}

Challenges by academic staff $(n=100)$

Challenges Frequency Percent

Delay in payment7575.0

Leadership style6868.0

Career Development 4949.0

Conducive work environment 3939.0

Excessive number of students 2020.0

Lack of adequate well-resourced libraries 1212.0

Lack of recognition 1313.0

Heavy workload 55.0

Table 1 indicates that majority of the academic staff, 89 percent, pointed out that there is poor remuneration in the workplace environment and that there is high rate of attrition and low retention. While majority at 75 percent indicated that there is delay in payment in private Universities in Southern highland zone, 68 percent felt that leadership style is wanting. Other challenges was career development cited by 49 percent, lack of security in private universities, lack of recognition of academic staff for the work done and lack of adequate well-resourced libraries. These challenges are resonate with extrinsic and intrinsic factors of Herzberg theory of motivation. The same echo findings by (Talha,2013).The finding simply that major it you the lecturers quit from the work place due to poor remuneration, employment quality, payment, type of contract such as permanent, temporary.

Academic staff complained flow salary as a critical factor which affects their decision to remain in workplace environment. This also concurred with Yusuf (2010) who as sorted that more than 50 percent of academic staff whole $\mathrm{ft}$ professional teaching in Florida mentioned low payment as the major reasons for their leaving.

Similar In Texas, Liza et al., (2008) interviewed lecturers who left teaching, within three years of their entrance and all mentioned low remuneration as their major reason for quitting out of the profession. An analysis of the challenges identified by the academic staff, administrators, and by students in Southern highland Zone in Tanzania revealed that the major challenges in workplace environment were lack of administrative strategies for retention. Some Universities had administrative strategies in files yet they were not implemented at all. From the study, findings revealed that attrition can be prevented through providing precautionary tools such as improving the workplace. Employees expect a work area, where they can utilize their abilities and satisfy their basic needs. 
Workplace had a profound impact on workers and tends to live within the organization as long as they wish. Is one of the factors that affect employees' decision to stay with the organization or quit. The retention could be enhanced with various administrativestrategieshenceprivateuniversitiesmanagerandadministrators should improve the workplace because; education for sustainable development is a key instrument to achieve the sustainable goals. Lecturers' duty is to provide knowledge, skills, values, attitudes, and habit of learners so as to empower student's to own education which contributes to sustainable development. Education therefore is the pillarforachievementsustainabledevelopment.PrivateuniversityinSouthern High land Zone should retain a cade micstaffso as toatta in quality education for sustainable development at all level of education.

Null Hypothesis One was looking if there is no significant relationship between leadership Style and academic staff decision to remain in private Universities in Southern Highland zone, Tanzania. Chi Square was used to test the hypothesis. The findings indicated that employers and workers need positive treatment and relationship at workplace, how leaders interact to and deal with workers every day can shape their attitudes positively or negatively. The leadership of employers is essential to the development of successful employees. The third null hypothesis set out to determine if there was relationship between leadership style and academic decision to remain in the universities. Chi Square test was used and results are presented in Tables 2

Table 2

\section{Chi-Square tests for relationship between Leadership and staff retention}

\begin{tabular}{|l|l|l|l|}
\hline & Value & Df & Asymp. Sig. (2-sided) \\
\hline Pearson Chi-Square & $3.137^{\mathrm{a}}$ & 4 & .535 \\
& 4.174 & 4 & .383 \\
\hline Likelihood Ratio & 40 & & \\
\hline
\end{tabular}

$5 \mathrm{~b}$. The minimum expected count is $.60 \mathrm{~b}$.

Given that obtained p -Value is greater than 0.05, we fail to reject the Null Hypothesis and conclude that there is no significant relationship between leaderships tyle and the decision of academic staff to remain in the private universities that were sampled. The decision to quit would be as a result of other factors but not necessarily leadership style.

Table 3

\section{Chi-Square Tests Efforts University use to retain lecturers}

\begin{tabular}{|l|l|l|l|}
\hline & Value & Df & Asymp. Sig. (2-sided) \\
\hline PearsonChi-Square & $6.463 \mathrm{a}$ & 2 & .039 \\
Likelihood Ratio & 8.742 & 2 & .013 \\
\hline N of Valid Cases & 40 & & \\
\hline
\end{tabular}

a. 2 cells (33.3 percent) have expected count less than 5 .

b. The minimum expected count is 6.463 for Pearson Chi-Square (2- sided) P Value is less than alpha therefore we reject the Null Hypothesis From Table 3, the calculated p-value was 0.039 which was less than 0.05 level of significance; therefore we rejected the null hypothesis and concluded that there was significant positive relationship between academic staff retention and education sustainable for development in private universities in Southern Highland Zone, in Tanzania.

\subsection{Summary of the Study Findings}

Workplace was seen top lay pivotal role for academic staff retention in private universities. However the issue of low retention of academic staff globally, is indeed worrying, hence the need to curb it. Various studies from the literature reviewed confirmed the fact as most universities suffer attrition and low retention of academic staff. The study set out to answer three research questions and the current study was guided by motivation theory of Fredrick Herzberg: Two factors, namely hygiene and motivation factors. The study used convergent parallel mixed methods research design with cross-sectional survey and phenomenology as corresponding quantitative and qualitative research designs. The study targeted a sample size comprised of 250 participants. 
It was delimited to academic staff, administrators, university students, and Human Resource Managers (HRMs). Probability sampling and non-probability sampling techniques were used. In probability sampling-stratified, systematic and simple random sampling was used to select academic staff, administrators and university students. Non probability purposive sampling was used to sample HRMs. Research instruments were questionnaires, interviews, and document analysis. Data analysis was done separately and then merged during report writing. Quantitative data from questionnaires were an analyzed using SPSS while qualitative data from interviews were transcribed; open coding, axial coding, categorized into data excerpt, or themes and narrative. The test for null hypothesis was done using Chi- Square. The main findings of the research were summarized and presented based on the themes of research questions: The frequencies of career development, allocation of rewards regarding work and work environment show the highest values in relation to their perceived level of retention with concern. It means that the academic staffs are more inclined towards their career growth, rewards and want to work in workplace where they get support from their colleagues. Hence work place should be in such a way that the organizations treat their employees as the most valuable assets and have to take care of them in order to achieve the organizational goals.

\subsection{Research Question 1}

The study was interested to find out if motivation factors in the organization contribute to academic staff to decide to remain in private universities in Southern Highland Zone, Tanzania. Employee recognition could be verbal praise or written has the capacity to improve organization loyalty, motivation, and perseverance at no extra charge. Individual skill recognition is restricted by age, and motivates positive behavior, ethics, teamwork, confidence, and growth in all employees is very crucial. Hence, skill recognition, appreciation, ranging from verbal praise to incentives rewards, and development enhance individual effectiveness, and retention in the workplace. A c a d e m i c s t a f fattrition could be minimized if private universities could put more emphasis one xtrinsic factors such as staff development, remuneration, supervision, recognition, promotion, and increment and overtime pay. Private universities need to introduce and implement performance-based pay to motivate the academic staff. Academic staff who works hard should be paid more. This will attract external and internal employees. In addition, intrinsic factors such as recognition could be by the word of gratitude or kind, appreciation, promotion, giving sympathetic gesture when a lecturer is sick and offering house allowances.

\subsection{Research Question 2}

The second research question investigated how Leadership style contributes to academic staff decision to remain in private universities in Southern Highland Zone, Tanzania. Based on the findings, most of the university managers in private universities in Southern Highland Zone use autocratic leadership style, while a few used democratic, laissez-faire, and situational leadership styles. How one interacts, deals with workers every day can shape their attitude for positive or negative change. Leadership is crucial to the development of successful employees. Happy employees are likely to be more productive than their disgruntled or resentful counterparts. There is no one way of leading the university. In general, managers are the climate makers in the work place. Hence, university managers need to appreciate and recognize the work done by academic staff, to spent time listening to lecturers and have positive attitude towards lecturers. University managers need to provide conducive workplace, professional development, resources that support effective teaching and learning as the main responsibilities of managers and administrators of private universities. By so doing, administrators would be helping the academic staff to remain in private universities. Generally, university managers need to use varieties of styles in the workplace since in the universities there are lecturers with diverse characteristics and behavior.

The findings revealed that most effective managers use varieties of leadership styles including transformational and transactional leadership styles for better results. This is in agreement with that of Butten (2013) who contended that leader ship should play the role of motivating employees and use all varieties of leadership styles for enhancing retention. There is a need to offer leaders and managers refresher courses in order to enhance communication and management skills in the workplace environment. According to Butten added that lecturers usually leave the leader and not the job.

\subsection{Research Question 3}

Challenges identified in the workplace environment included: poor remuneration in the workplace leading to high rate of attrition and low retention, delay in pay men tin private universities in Southern Highland Zone, a wanting leadership style, lack of job security and poor academic staff career development. 
Private universities depend a hundred percent from students' tuition fees. Very low lecturers' remuneration, Tanzanian Commission of Universities (TCU) puts much pressure on private Universities by reducing the number of students during registration. Very low academic retention; another challenge is Research stagnation, hence, private universities; failed to excel in research writing however research is the key force to the university to attain sustainable development. Other challenges were large number of students in a single class, lack of recognition of academic staff for the work done, lack of adequate well-resourced libraries, and heavy work load and most of the private universities lack administrative strategies for retention. However, where they existed they only had them in files but not implemented.

\section{Conclusion}

Sustainable development in university education is possible if quality academic staff retention is given deserved attention. Without lectures retention and sustainability development of university education in private universities in southern highlands zones will remain an elusive endeavor. This study was on academic staff retention in private Universities in Southern Highland Zone in Tanzania as strategies for sustainable Development. The researcher makes the following inferences: Firstly, all private universities in Southern Highland Zone in Tanzania sampled for the study fell short of pertinent issues such as lack of motivating academic staff and enough security in workplace. The university managers were not serious in providing reward, recognition and appreciation to the lecturers as evidenced from the findings.

Secondly, the study concluded that an autocratic leadership style is mainly used in Southern Highland Zone. Hence, leadership strategies or styles are wanting and need to be varied in order to accommodate all the parties involved for harmonious stay and conducive work environment. However, leadership style such as Autocratic style; was mentioned as contributing greatly to academic staff attrition from the workplace as it was also cited that academic staff leave the leadership and not the work. Therefore managers need to use varieties of leadership styles as they manage their universities.

Thirdly, the main challenges facing managers in private universities: declining sources of income and rising cost. Private universities depend on hundred percent from students' tuition fees. Very low lecturers' remuneration, Tanzanian Commission of Universities (TCU) puts much pressure on private Universities by reducing the number of students during registration. Very low academic retention; Research stagnation, is another challenge facing private universities; majority of the private universities failed to excel in research writing however research his the key force to the university tatter in sustainable development. Lack of facilities such a se-books, e-journal, computers, classes, and above all inadequate communication and opportunity by lecturers to share in the decision making process made them to consider quitting from their work place. The administrators of these universities therefore need to put in place proper and workable strategies that could be used to enhance retention of academic staff in the sampled institutions.

\subsection{Recommendations for Theory}

The study adopted Herzberg theory in interrogating the retention of academic staff as strategies for education sustainable development in private universities as a factor impinging academic staff retention implementation. Academic staff tends to remain in the universities as long as they are satisfied with workplace he commission of effectiveimplementationofadministrativestrategiesinworkplaceaffectacademic staff's decision to remain with the university or to leave. Consequently, the study recommends further interrogation of the role played by administrative strategies as a motivating factor in enhancing overall private universities' effectiveness and improvement. 5.3 Recommendations for Practicei. Based on the findings and conclusion of the current study, recommended that: The government and other stakeholders need to involve in the funding operations of private universities by giving grants and scholarships to the private universities students to boost the economic situation soft he private universities. The continuous cash flow would greatly assist private universities to promptly pay academic staff and so boost the working morale. ii. The $\mathrm{u} \mathrm{n}$ ve r s i t y m a n a e r s s h o u ld t o c klibrary with e-books, e-learning, computers and varieties of e-journals that are relevant to the courses offered. iii. Private universities, in spite of their different circumstances, need to practice institutional transparency in their operations such as promotion procedures, provision of resources, opportunities for staff development, study leave, contact, competitive remunerationandsabbaticalleavetoensurethatlecturersarekeptsatisfiedand motivated with their job. Universities will have to ensure that there are unambiguous, comprehensible promotion's guidelines. Additionally, clear competitive salary packages should be designed for academic staff. vi. 
Managers in private university in Southern Highland Zone should use varieties of leadership styles, relate well with their academic staff and involve the academic staff in decision making in the university so that workers may feel at home thus o w n t h e o r g a n i z a t i o $\mathrm{n}$; moreover, managers in private university in Southern Highland Zone should seek funds elsewhere and not depend on students' fees alone

\section{References}

Ahuja, S., \& Kumar, R. (2012). Review: research methodology: a step-by-step guidefor beginners, university of Western Australia. SAGE publications.

Akanbi, P. A. (2013). Influence of extrinsic and intrinsic motivation on employees Performance. Retrieved on May, 2014; Effect of motivation; Bayelsa State Nigeria.

Bangi, Y. I. (2014). The influence of management practice and attitudes on Employee turnover, Kibaha District coast region. University of Dar Es Salaam The international Journal of business \& management. 2(9), 3342.

Batten, F. (2013). School of leadership and public policy. Garretthall: 235 McCorm road. Charlottes ville Virginia America.

Body, D. Grossman, P. Ing, M. Lankford, H. Loeb, S., \& Wyckoff, J. (2009).

The influenceofUniversityadministratorsonlecturers retention

decisions. Http:// w w w .L ecturer' spolicy research.org.

Blazer, C .(2006). Teacherstransferandturnover. Miami-Dade county public secondary schools. Biscayne Boulevard. Miami, Florida. USA.

Calhoun, T. (2009). Lecturers jobsatisfaction and employees turnover. MichiganStates, USA.

Dillow, S. A. (2013). Education statistics services institute American institutes for research. University of Missouri; Columbia.

Gberevbie,D.E.(2009).RetentionStrategiesinLagoscivilserviceinNigeria. African review. An international multidisciplinary journal;3(3), 226-243.

Herzberg, F. (1993). Motivationand Innovation: Whoareworkers serving?California Management Review 22(2), 60-70

Kavenuke,P.(2013).Whatisthatkeepgoodlecturersinprofession teaching.University of Dar Es Slaam; Journals savap.org,pk 4(1), 19.

Kayuni,H.,\&TambulasiR.(2007).TeacherturnoverinMalawi's ministry of education: realities and challenges. International education journal,8(1), 89-99.

Lawler, E., \& Fuchs, K. (2010). Cornell University at its Sesquicentennial Strategic Plan for lecturers' retention. Washington: Washington University.

Leahy, T. (2012). Teaching staff turnover research. The academic profession: the professoriate in crisis higher education.

Lisa, G., Jos, J. J. , Beishuizen, B. J. \&Monique, L. L. (2017). The sustainable of Teachers professional development programme for beginning urban teachers, Cambridgejournal of education 47:1 150-151

Mapolisa, T. (2014). Staff Retention challenges in Selected Zimbabwe's public and Private universities: Returnee Lecturers perspective. Journal of Education policy and entrepreneurial research. (JEPER) 1(4), 92-102.

Marn, J.(2012). The impact of transformational leadership practices on job satisfaction of private University lectures. Retrieved on 12 June 2014; Journal for the advancement of science and Arts, 3(2), 331-342.

Miller, B. S. (2011). The revolving door: how leaders push teacher turnover. Georgia: Georgia State University.

Mkude, O. (2007). Challenges and opportunities facing academic staff. Highlights from African higher education: an international reference handbook colling wood for the partnership for higher education in Africa.

Muteswa, R. (2012). Impact of worker turnover in South Africa Karen: University of Kwazwulu. Natal: SA, 37(1), 61-78.

Mwangu,N.,\&Leshabari,M.T.(2008).WorkmotivationintheUniversityof Muhimbili in Dar es Salaam Tanzania. East African journal of public health 5(1), 32-37.

Mwita, E. (2013).Public universities in Tanzania challenges opportunities. Science research open access. Dar es Salaam University, Tanzania. 
Namasaka, D. Poipoi, M. Wesangeeula, L., \& Mamuli, C. (2013). Factors causing staff turnover atMasindeMuliro.University of science andtechnology.Nairobi: Kenya

Nderitu , S. (2014). Turnover of lecturers in Private Universities in Kenya: A case of Daystar and Pan

Africa Christian Universities. International Journal of Management Sciences 2( 5), 435- 449.

Ng'ethe,M. J. (2013). Determinants of academic staff retention in public universities in Kenya. Jomo Kenyatta University

Owuor,B.(2010).Academicmobilityandbraindrain:EastAfricanPerspective: paper presented at the director international relations and partners. Nairobi: Maseno Universit y.

Perden, S. (2013). The annual education statistics Report on: High lecturers dropout. Pienaar, C., \& Bester, C. L.(2008).Retention of Academics in the Early Career Phase.SA. Journal of Human Resource Management, 6 (2), 32 - 41.

Phrasisombath, K. (2012). Sample size and sampling methods. University of healthScience Vientiane: Laos

Platsidou, M., \& Diamantopoulou, G. (2009). Job satisfaction of Greek university professors:Isitaffectedbydemographicfactors,academicrankand Problems of higher education? In G. K. Zafis, Educating the Adult Educator: Quarterly Provision and Assessment in Europe, Conference Proceedings, EASREA-ReNAdET (pp. 535-545). Thessaloniki: Grafima Publications

Tickle, R. B. (2008). Public school teachers' perceptions of administrative support Mediating effect on their job satisfaction and intent to stay in teaching. Blacksburg, Virginia USA.

Veiseh, S., \& Veisi, H. (2014 ). Invetigating the Influence of Servant Leadership Style on Employee Retention (Case Study - Ilam Petrochemical Company). Indian Journal of Fundamental and Applied Life Sciences , 4(54), 3886-3893 .

Wambui,M.(2014).Managementpracticesonlecturersinhighereducation.Kenyatta university-Nairobi.

Wafula, G., Kirimi, B. M., Musiega D., and Kiman. K. (2013). An evaluation of Remuneration scheme in relation to staff turnover in Kenyan private universities: Case study of the Kenya Methodist University" Retrieved on 22nd November 2014. Internationaljournal for management science and technology 1(2),81-92.

Wasyanju, M. Kindiki, J. N., \& Kalai. J. M. (2012) Factors of attrition on quality of education. Research paper published by Moi University, Nairobi Kenya. 